\title{
Educação, Estado e poder: uma análise dos aspectos históricos presentes na atualidade
}

\author{
Education, State and power: an analysis of the historical aspects present today \\ Educación, Estado y poder: una analice de los aspectos presentes en la actualidad
}

Karina Pacheco Dohms

A educação ocupa um lugar central no desenvolvimento histórico brasileiro e as decisões tomadas em relação ao sistema de ensino, ao longo dos anos, sempre foram influenciadas a partir de variáveis econômicas, sociais, culturais, e políticas. Fábio Comparato $^{1}$, em seu livro Educação, estado e poder, originado a partir de três conferências, faz uma análise das diferentes orientações que a educação recebeu ao longo da República, e ressalta que somente conhecendo a sociedade e suas dimensões, será possível ter um claro entendimento do processo educativo. Apesar de passados alguns anos de sua publicação a obra mantêm sua atualidade, servindo de base para resgatar os aspectos que ainda estão presentes na contemporaneidade.

Fábio Comparato (1987, p. 13-14) inicia sua obra definindo o poder "como a faculdade de impor a sua vontade a outrem [...], um fenômeno próprio da vida de relações hie- rárquicas", lembrando que existem formas de relações sociais desenvolvidas fora desse sistema hierárquico. Afirma o autor que, desde Aristóteles, a ideia de uma sociedade política e do exercício do poder político sempre obteve origem em uma reflexão sobre a família. Destaca ainda que hoje é muito difícil entender essa aproximação, pois, se passamos da família para uma educação, fora dela pode parecer óbvio que o componente imposição é insuprimível. Apesar da Constituição Imperial, da Lei de Instrução Pública, do Ato Adicional, da Lei Provincial, entre outros, que começavam a reconhecer, valorizar e demonstrar preocupações em relação à educação buscando qualificá-la, foi

Doutoranda em Educação/PUCRS. Professora de Educação Física do Colégio Marista Assunção.

Recebido em: 05/07/2012 Aprovado em: 08/09/2012 http://dx.doi.org/10.5335/hdtv.13n.1.2516 
preciso criar estratégias para que as famílias enviassem seus filhos à escola, visto que até o final do século XIX a educação doméstica predominava. Isso remete as questões de "autoridade", discutidas pelo autor, representando "a influência determinante sobre o comportamento de outrem, em razão do prestígio moral, do conhecimento técnico ou científico, da habilidade ou experiência, do carisma" (COMPARATO, 1987, p. 17). O autor acredita que é possível perceber que o mundo das relações pessoais e nominadas passa a ser superado por um mundo de relações impessoais, estáveis, permanentes, independentes de pessoas determinadas. A autoridade docente pode ter duas funções distintas. Uma diz respeito a ensinar o aluno a se normatizar e a outra a de levá-lo a usar sua liberdade, "o poder é racional quando consegue resolver os problemas atuais da sociedade" (p. 31).

Para Comparato (1987, p. 46), "a questão educacional é influenciada não só pelas idéias dominantes, mas também pelo regime político", na qual o Estado é uma organização impessoal e permanente do poder, não havendo educação desvinculada da atividade política, pois é uma instituição política fundamental não podendo afastar esse dilema. $\mathrm{O}$ autor traz diferentes etapas da evolução política republicana no Brasil, que também influenciaram o sistema educacional do país. A República Velha (1891-1930) se caracterizou pela "descentralização de poderes, contra o centralismo monárquico, que era, sobretudo, patente no campo administrativo" (p. 47). Surgia a luta contra o analfabetismo, pois indivíduos analfabetos não podiam votar. Em 1920, tudo parecia ser resolvido no país graças à educação, que nos daria saúde. Também houve, com a fundação da Associação Brasileira de Educação (1924), o surgimento dos chamados profissionais da educação, fazendo, tais educadores, questão de afirmar que sua principal função era a educação, antes vista como uma missão num sentido quase religioso. A era getulista (1930-1945) determinou o liberalismo, pois "procurava-se passar do chamado Estado liberal para o Estado social. O Estado social significa a organização, pelos poderes públicos, das atividades sociais no sentido de realizar o maior bem-estar possível" (p. 56). Para Comparato (1987), foi durante o período da Quarta República (1946-1964) que a educação evoluiu de maneira muito dependente dos descaminhos do período e demonstra, mais uma vez, que a questão educacional não pode ser, absolutamente, tratada de modo desvinculado de todos os outros fatores econômicos e políticos.

No Brasil houve necessidade de realizar lutas por liberdades democráticas, juntamente com o aprimoramento de direitos políticos para então ser possível garantir os direitos sociais. A educação sempre foi e será um investimento necessário para a sociedade, uma luta constante para que haja maior valorização por parte dos governantes e sociedade. Na opinião de Comparato (1987, p. 82), isso resume a consciência da exigência de uma maior igualdade, mas quando a consciência da desigualdade se torna muita aguda, as exigências para superação desse desequilíbrio tendem naturalmente ao máximo, não sendo "possível desenvolver uma educação igualitária num regime que não seja igualitário, pois as duas coisas se impli- 
cam reciprocamente". A educação precisa formar cidadãos para essa vida democrática e Comparato (1987, p. 120) lembra que a educação para a democracia "precisa enfatizar a supremacia dos direitos humanos, apontando para a dignidade eminente da pessoa humana". Contudo, destaca que o importante não é discutir a respeito das finalidades da sociedade, da razão de se viver ou o objetivo da vida, mas discutir sobre os meios. $\mathrm{O}$ Estado também exerce papel importante no campo do ensino, desenvolvendo políticas sociais específicas a cada contexto que se passava e a política educacional não é um caso particular dessas políticas sociais.

Fábio Comparato nos faz perceber que, ainda hoje, há uma necessidade de existir seres sociais que produzam ações e conquistas para a constituição de direitos sociais. A educação sempre será um investimento importante e cada vez mais necessário para a sociedade, em busca de uma maior valorização e reconhecimento da sociedade em geral, e, principalmente, por parte de nossos governantes, mas que seja continuamente uma fonte de esperança, também, daqueles que não possuem condições mínimas de acesso.

\section{Nota}

1 COMPARATO, F. Educação, Estado e Poder. São Paulo: Editora Brasiliense, 1987.

\section{Referência}

COMPARATO, F. Educação, estado e poder. São Paulo: Brasiliense, 1987. 